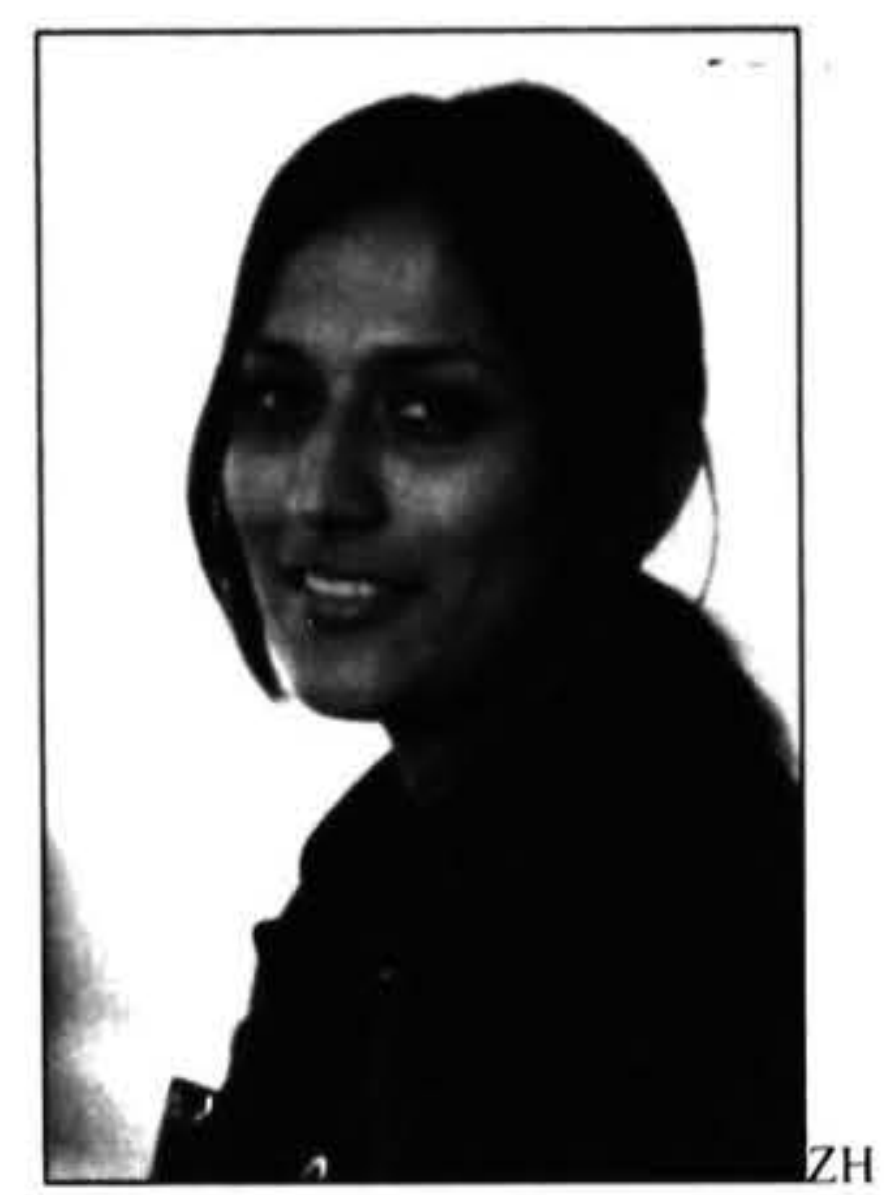

\title{
OCCUPATIONAL STRESS IN THE SERVICE SECTOR: A NEW DIMENSION
}

\section{Zeenobiyah Hannif}

School of Management and Marketing, University of Wollongong, NSW

\section{Felicity Lamm}

\section{Department of Management and Employment Relations, The University of Auckland}

\section{Karen Lo}

Masters of Commerce Student, Department of Management and Employment Relations,

The University of Auckland

\section{Jeffrey Lu}

Masters of Commerce Student, Department of Management and Employment Relations,

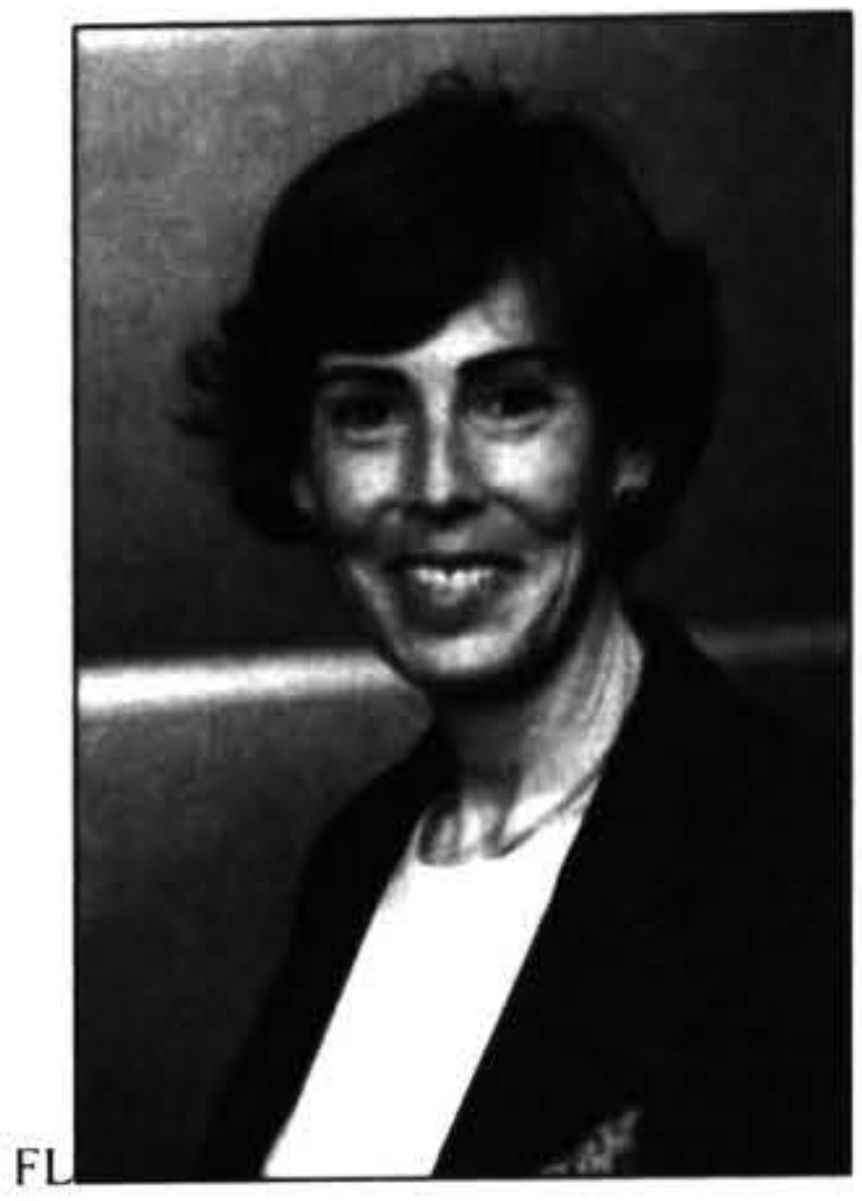

The University of Auckland

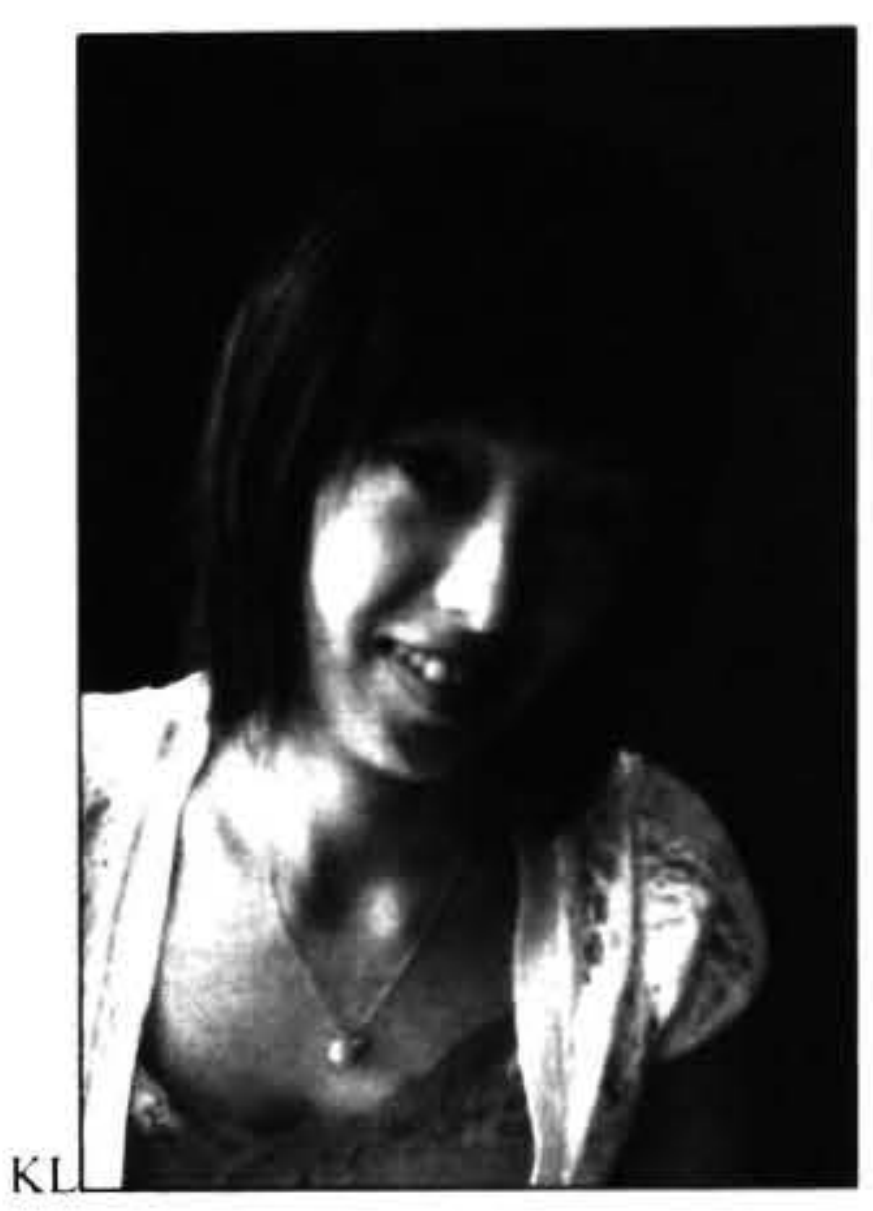

\section{Abstract}

Previous research on occupational stress is limited in that it has tended to focus on the individual and is frequently. located within occupations that are deemed to be stressful, such as nursing and policing. The intention of this paper is to broaden the scope of analysis by investigating a range of employment factors (i.e. heavy workloads, interpersonal relationships and organisational factors) which can contribute to stress amongst workers and to include more industry. sectors. In particular, this paper endeavours to draw attention to occupational stress amongst workers in emotionally. demanding, so-called "low risk industries" - namely the call centre and hospitality industries, and to explore their perceptions of stress, their attitudes concerning managing stress and their responses to the inclusion of stress detailed in the Health and Safety in Employment Amendment Act, 2002. Findings from two studies indicate that working in the hospitality and call centre industries can be stressful and that most workers are vulnerable in terms of their poor working conditions and low wages. Findings also show that, consistent with other studies, there was low trade union presence and a high rate of casualisation and staff turnover in each of the industries. At the same time there was a lack of overt conflict between management and workers, with an apparent close alignment of goals between the two parties and a style of management that could be described as unitarist.

\section{Introduction}

There is growing recognition in the literature over the past twenty years that occupational stress can contribute to work-related ill health, with negative effects on both physical and psychological well-being (Caplan, Cobb, French, Harrison, and Pinneau, 1975; Perrewe and Anthony, 1990; Bohle and Quinlan, 2000; Smith 2003). Occupational stress is also associated with reduced work output and can contribute to increased accidents, absenteeism, employee turnover and poor employee performances (Caplan, Cobb, French, Harrison, and Pinneau, 1975; Perrewe and Anthony, 1990; Spector, 2003). Moreover, it has the potential to spill over to affect employees' private life, causing marital, friendship or community problems (Kahn and Byosiere, 1992: Sauter, Murphy, and Hurrell, 1990). These outcomes of occupational stress can result in significant economic and social costs for both employers and employees (Watkins, 2003). 
Recently, stress and fatigue have become more topical in New Zealand and overseas as a result of legal and regulatory controls on the levels of stress and fatigue that individual workers can endure. For example, occupational stress was officially recognised as a "hazard" (refer to Section 8) under the Health and Safety in Employment Amendment Act, 2002. Such changes have been largely informed by significant developments in New Zealand's common law as demonstrated in two leading decisions from High Court and Court of Appeal respectively namely Brickell $v$ Attorney-General' and AttorneyGeneral v Gilbert ${ }^{2}$ (Scott-Howman and Walls, 2003). In essence, these cases confirmed that the employer has a general duty of care to safeguard their employees not only from physical harm but also from mental harm (ScottHowman and Walls, 2003). Furthermore, New Zealand and UK court cases ${ }^{3}$ have supported the notion that counselling alone is not sufficient to allow an employer to discharge his/her obligations under both statue and common law, (Scott-Howman and Walls, 2003). There has to be demonstrable evidence that the employer has endeavoured to eliminate or isolate or minimise the sources of stress. Therefore, the inclusion of stress and fatigue in the Amendment to the Health and Safety in Employment Act has meant that all employers must be cognizant of the employment conditions of their workers, irrespective of the type of work, and must implement systems that treat stress and fatigue as any other workplace hazard (refer to the Department of Labour publication Kev Changes to the Health and Safets in Emploiment Act. 2003).

However, research on occupational stress is limited as it has it has tended to focus on the individual, and/or is frequently located within occupations that are deemed to be stressful, such as nursing and policing. Therefore, there is a need to place the individual within the context of the workplace. There is also a need to investigate a range of employment factors (i.e. heavy workloads, interpersonal relationships and organisational factors) and to extend the investigation to include more industries.

The purpose of this paper therefore, is to draw attention to occupational stress amongst workers in "low risk industries" that utilize emotional and aesthetic labour namely the call centre and hospitality industries. Based on data from two studies, it is also intended to explore their perceptions of stress, their attitudes concerning managing stress and their responses to the inclusion of stress detailed in the HSE Amendment Act, 2002. In particular, the paper commences with an overview of the service sector. The paper also sets out a brief outline of what is meant by "emotional" and "aesthetic" labour as well as arguing for a more multidimensional view of occupational stress. The paper highlights the key themes of both studies and concludes that there is a need for more research in this area.

\section{Profile of the Service Sector}

The service sector accounts for approx 70 per cent of total employment across OECD countries and employs approximately 75 per cent of the labour force in NZ, Canada and the US. Interestingly, the service sector's contribution to employment growth in NZ between 1990 and 2002 is the fourth highest in the OECD. One of the largest industries in the service sector is hospitality, which comprises of accommodation, cafes and restaurants. This industry employs approximately 6 per cent of the New Zealand's labour force and represents 3.5 per cent of all New Zealand businesses. Although cafes and restaurants represent the largest number of businesses in the hospitality category, accommodation businesses represent the second largest group, making up 35.3 per cent of the hospitality industry. The hotel businesses represent the largest group within the accommodation industry and employs approximately 51.6 per cent of employees within this industry.

Call centres have a presence in multiple industries and therefore are yet to be officially classified as "an industry" under the ANZSIC. Nonetheless, New Zealand has approximately 350 call centres, operating 11,000 call centre seats and employing 18,000 workers. The total value of the call centre market was estimated to be $\$ 760$ million in 2002 (ACA, 2002). The 2002 figures indicating that call centres are now handling an estimated 68 per cent of all customer contacts (ACA, 2002).

Both the hotel and call centre industries share a number of common features. In particular, both experience stiff regional and international competition. In each of the industries there is a focus on cost minimising strategies while at the same time improving quality of service delivery, thus creating an ongoing tension between trying to achieve increased targets with decreasing resources. The two industries also share a number of common trends. These trends are:

- Increased prevalence of non-standard working arrangements;

- Decline of unionised workers;

- Extension of working hours with shifts running 24hours and the use of more precarious employment arrangements to service these demands:

- A more youthful labour force;

- Increased use of "emotional" and "aesthetic" labour.

\section{"Emotional " and "Aesthetic" Labour in the Service Sector}

Hochschild (1983) first coined the term "emotional labour" in her work The Managed Heart: Commercialization of Human Feeling and subsequent research in this area has been dominated by empirical studies undertaken in the service sector. Hochschild (1983:7) defines emotional labor as "the management of feeling to create a publicly observable facial and bodily display [which] is sold for a wage and therefore has exchange value." As with other forms of labour, emotional labour has become commodified. In an attempt to illustrate the consequences of commodification of feeling in service industry, Hochschild (1983) differentiates between "surface acting" and "deep acting" of emotional labour, in that surface acting involves a superficial expression of the appropriate emotions while deep acting involving the internalizing of actual feeling 
along with the expression of the emotions. Hochschild (1983) argues that these distinctive aspects of emotional labour performed in the commercial sphere (namely commodification, the structured inequality in relation to customers and managerial imposition of feeling rules) mean that emotional labour has deeply harmful consequences for workers in the service sector. The consequences are particularly harmful because the management imposed feelings rules imply that workers are not only required put on a "surface act" to customers but are required to internalize the feelings they are meant to display (Hochschild, 1979; 1983).

As an extension of Hochschild's analysis of emotional labour, Nickson and Warhurst (2000) suggest that employers in interactive services rely largely on the physical appearance or more specifically, the embodied capacities and attributes of those to be employed or are employed, a reality termed as 'aesthetic labour'. While Hochschild focuses on emotions and their internal management, the concept of aesthetic labour highlights the importance of the outward display of interactive service workers. The authors (Nickson et al. 2000) define aesthetic labour as "a supply of embodied capacities and attributes possessed by workers at the point of entry into employment". Employers then mobilize, develop and commodify these capacities and attributes through processes of recruitment, selecting, and training, transforming them into competencies that are intended to produce a favourable interaction with customers (Nickson and Warhurst, 2001). These embodied capacities and attributes, according to Nickson and Warhurst (2001), include not only physical appearance in terms of height, physical outlook and body shape but also dispositions such as language, dress code, manner, demeanor and even accent. In their exploratory study on interactive service industries in Glasgow, Nickson et al. (2000) found that the need to look good and sound right did exist and was an emerging feature of contemporary work and employment, particularly in designer retailers, boutique hotels, and style bars and restaurants, often known as 'style labour market'.

Nickson and Warhurst's (2000) work on aesthetic labour also indicates the commodification of employees' styles and the fit of that style with the image of the organizations. However, unlike Hochschild's pessimistic view on emotional labour that commodification of emotion in contemporary society is dehumanizing and alienating in nature, Nickson and his colleagues (2000) argued that the commodification of these embodied capacities and attributes was often accepted by front-line workers. The acceptance of aesthetic standards also points to the fact that if workers adopt a particular style of self-presentation then they are afforded entry in the form of community with customers who have a similar style (Korczynski, 2002; Nickson and Warhurst, 2001). Moreover, employers' search for competitive advantage through aesthetic labour has also prompted a shift in the nature of labour market from servility towards "labour aristocracy" in which those workers employed as aesthetic labour in the 'style' labour market enjoy marginally higher remuneration and other benefits.

\section{Occupational Stress}

One of the major weaknesses of orthodox research on occupational stress is that it has been dominated by psychological and medical approaches which have meant that occupational stress is largely attributed to individual behaviours such as personality traits and therefore, coping mechanisms are primarily initiated and managed by the individual (Cartwright, Cooper and Murphy, 1995; Semmer, 1997; Parkes and Sparkes, 1998). Authors who pursue these lines of inquiry have been criticised for their narrow focus on the individual and for fostering a 'victim-blaming ideology' rather than recognising other environmental sources of stress and investigating underlying problems and solutions that incorporate a wider number of factors (Otto, 1985; Cox, 1988; van der Hek and Plomp, 1997; Cartwright and Cooper, 1997; Cooper, Dewe and O'Driscoll, 2001; Hart and Cooper, 2002).

In addition, there has been a growing recognition that managing occupational stress is complex and multifaceted, and therefore requires a more holistic approach. There has also been a recognition that employment factors (e.g. wages and conditions, employment relationships, company policies, etc.) as well as the roles played by the different interests groups (employers, trade unions and government agents) are important inclusions in understanding the complex nature of occupational stress (refer to Bohle and Quinlan, 2000; Smith 2003; Bohle, Quinlan, Kennedy, and Williamson, 2004: Gold, 2005).

Taking a more multidimensional view of stress, Cooper, Dewe and O'Driscoll, (2001) argue that sources of stress can be grouped into three broad categories: job-specific sources, organisational sources and individual sources. The first two categories are external to the individual and are frequently referred to as "environmental" sources of stress. Cartwright and Cooper (1997) identified six environmental sources ${ }^{4}$ as follows:

1. Factors intrinsic to the job itself

\section{Roles in the organisation}

3. Relationships at work (with supervisors, colleagues, and subordinates)

\section{Career development issues}

5. Organisational factors (e.g. organisational structure and climate)

6. The home-work interface. 


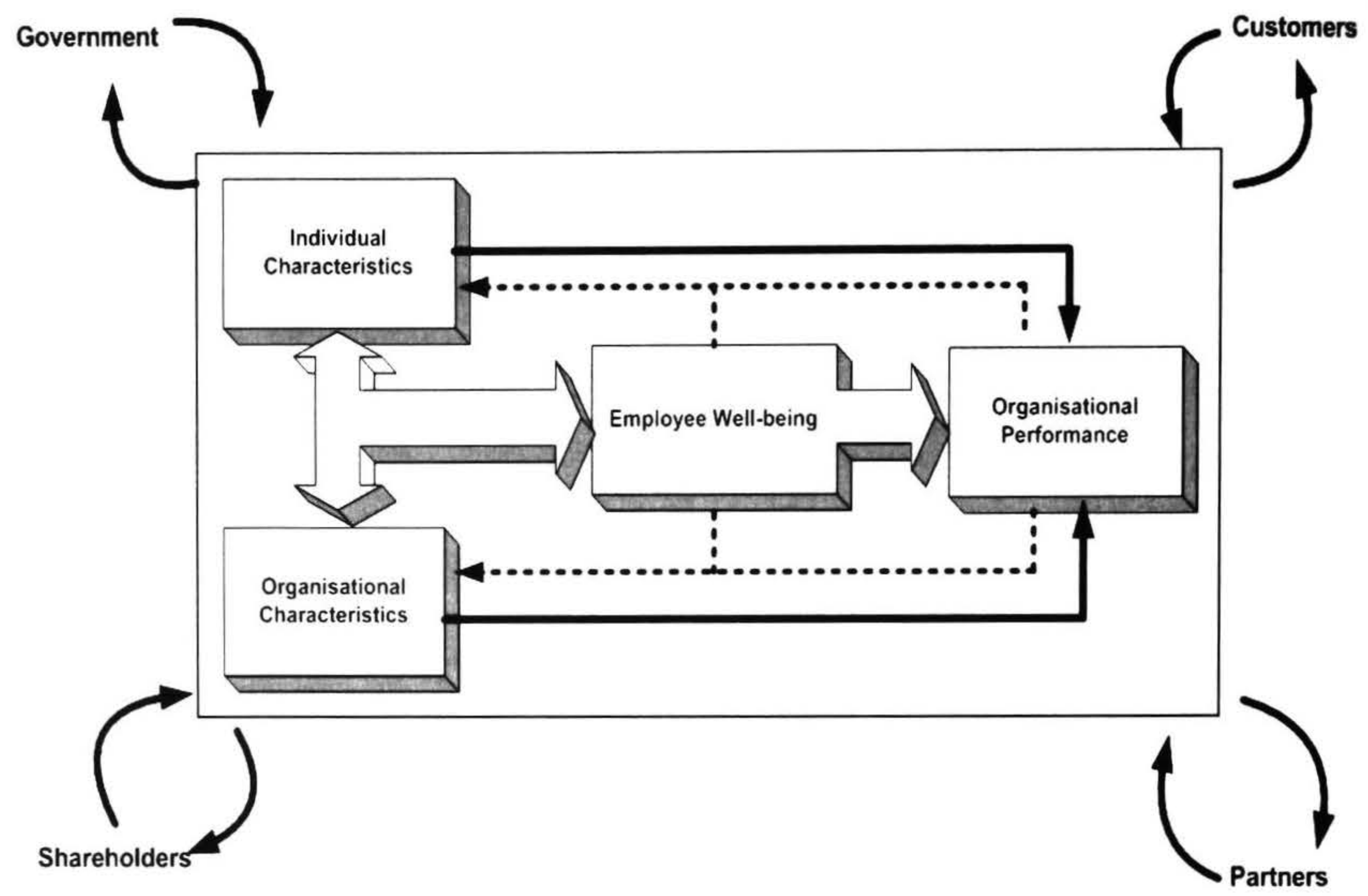

Cox (1998) and Hart and Cooper (2002) have incorporated the six environmental sources together with some employment relations features to create a model, as illustrated in Figure 3. The key strength of their model is that it expands the notion of occupational stress by marrying some of the best aspects of psycho-medical perspective and employment relations. Unlike conventional psycho-medical approaches, this model not only recognises the interaction between individual and organisational factors and their effects on the employee's well-being at the micro level, but it also incorporates a strong link to organisational performance. Moreover, although a number of researchers have highlighted the negative impacts of occupational stress on organisational performance in terms of the quality of the working environment and employee attitudes and behaviours, this factor is often overlooked in stress research (Kompier, Geurts, Grudemann, Vink and Smulders, 1998; Reynolds and Shapiro, 1991). At the macro level, external factors, such as government legislation and share holders' demands, influence the core elements of the organisation, such as employee performance (Hart and Cooper, 2002). The core elements are also inter-related and can influence each other. For example, the organisation's policies and practices will influence how the team operates under certain conditions.

By amalgamating Hart and Cooper's (2002) model with Cartwright and Cooper's (1997) six environmental sources as well as incorporating the employment relations levels of analysis, it is possible to create a framework sufficiently robust to investigate stress in the hospitality and call centre industries as shown in Figure 2 below.

Figure 2: Multi-dimensional approach to stress in the service sector.

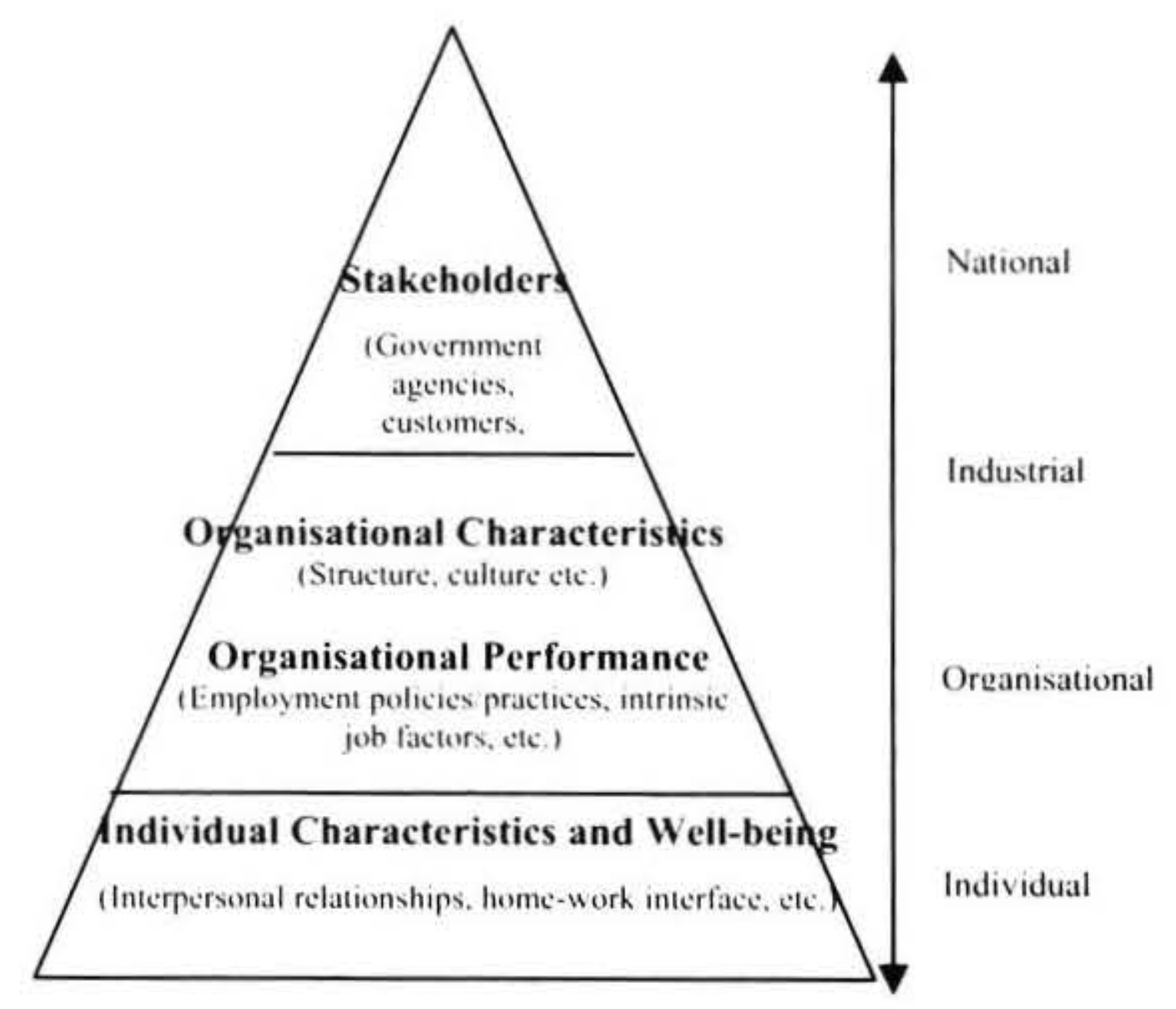

\section{Methodology}

Underpinning the study are the following research questions: 
- What are the experiences of occupational stress amongst employers and employees in the hotel and call centre industries?

- What are their perceptions and attitudes about the responsibilities of managing stress?

- How do the hotel and call centre markets approach the issue of occupational stress?

Two separate studies were conducted in which a qualitative approach was applied in each of the studies. In both studies case studies were developed and face-to-face interviews with participants was the primary source of data collection. The four case studies (two from hospitality and two from call centre sector) were selected to reflect the amount of diversity that exists in the respective industries.

The hotel case studies can be distinguished in terms of their business activities, the age and size of the business as well the type of employees, (e.g. the number of men and women workers), as outlined in Table 1. Hotel A is part of an international chain and has been in operation since 2001. The hotel tends to attract younger employees as it offers more overseas transfer opportunities, than Hotel B. Conversely, Hotel B is locally owned, has been in operation for over 26 years and has twice the number of staff (particularly female staff) as Hotel A. However, it is important to note that Hotel A has subcontracted its housekeeping services (28 staff).

Call Centres A and B also differ from one another. On one hand, Call Centre A is a small outsourcer that handles only outbound calls and has been in operation for 14 years. The majority of the workforce is made up of younger workers, particularly females and students $(60 \%$ of workers are 24 years or younger). Call Centre B, on the other hand, is a large in-house call centre that services inbound calls, and has been in the market for 38 years. The call centre mainly attracts women looking to return to the workforce, and it has a relatively large proportion of workers aged $40-60+$ years $(30.8 \%)$.

As illustrated in Tables 2a and b, as there are also differentiating employment arrangements between the case studies in terms of the working hours, the different provisions, leave entitlements, the level of trade union membership and staff turnover. With reference to working hours, there is no limit on the amount of overtime workers can do in Hotel A and the breaks between shifts -8 hours - are shorter than those in Hotel B. However, there were constraints in place to make working overtime less attractive; for example there are no overtime penal rates or days off in lieu and any proposed overtime requires written authorisation from management. While the provision of breaks and access to free meals are generally the same across both hotels, the housekeeping subcontractors in Hotel A are not provided with free meals.

In Hotel B employees must have a minimum of a 12-hour break in between shifts and can only work a maximum of 10 hours of overtime per week. However, the Hotel had a more flexible approach to working overtime compared to Hotel A, requiring only mutual agreement between the employee and the supervisor for working four consecutive 10-hour shifts. Furthermore, although both hotels complied with the basic minimum standard of leave entitlements, Hotel B went beyond legislation by offering unlimited accumulation of special leave.

The concept of overtime is not relevant to either of these call centres. Within Call Centre A the hours are totally variable and can range from 0 to 70 hours of work a week. In Call Centre B employees are only able to work a maximum of 38 hours a week spread over four days from Monday to Sunday including a compulsory Saturday to maintain part-time employee status. In both cases, wages are always paid at the same invariable hourly rate.

Table 1: Characteristics of the case studies.

\begin{tabular}{|c|c|c|c|c|}
\hline & Hotel A & Hotel B & Call Centre A & Call Centre B \\
\hline Type of Business & $\begin{array}{l}\text { International } \\
\text { Franchised }\end{array}$ & Locally Owned & Outsourcer & In-House \\
\hline Age of Business & 4 years & 26 Years & 14 Years & 38 Years \\
\hline $\begin{array}{l}\text { Number of } \\
\text { Employees }\end{array}$ & $\begin{array}{l}\text { Full-time } \\
\text { Male: } 29(37 \%) \\
\text { Female: } 24(30 \%) \\
\text { Part-time } \\
\text { Male: } 17(22 \%) \\
\text { Female: } 9(11 \%) \\
\text { Total: } 79 *\end{array}$ & $\begin{array}{l}\text { Full-time } \\
\text { Male: } 43(28 \%) \\
\text { Female: } 69(45 \%) \\
\text { Part-time } \\
\text { Male: } 11(7 \%) \\
\text { Female: } 32(21 \%) \\
\text { Total: } 155\end{array}$ & $\begin{array}{l}\text { Casual } \\
\text { Male: } 49(37 \%) \\
\text { Female: } 83(63 \%) \\
\text { Total: } 132 \\
\text { (34 Seats) }\end{array}$ & $\begin{array}{l}\text { Part-time } \\
\text { Male: } 8(14 \%) \\
\text { Female: } 49(86 \%) \\
\text { Casual } \\
\text { Male: } 30(25 \%) \\
\text { Female: } 90(75 \%) \\
\text { Total: } 177 \\
(160 \text { Seats) }\end{array}$ \\
\hline Age of Employees & $\begin{array}{l}79 \% \text { under } 30 \text { years } \\
\text { old }\end{array}$ & $\begin{array}{l}56 \% \text { under } 30 \text { years } \\
\text { old }\end{array}$ & $\begin{array}{l}74 \% \text { under } 34 \text { years } \\
\text { old }\end{array}$ & $\begin{array}{l}62 \% \text { under } 34 \text { years } \\
\text { old }\end{array}$ \\
\hline
\end{tabular}

* Excludes housekeeping contractors. 
Table 2a: Employment conditions as of February 2004.

\begin{tabular}{|c|c|c|}
\hline & Hotel A & Hotel B \\
\hline $\begin{array}{l}\text { Working } \\
\text { Hours* }\end{array}$ & $\begin{array}{l}\text { - Overtime Payment: normal rate } \\
\text { - Requires authorisation and signed mutual } \\
\text { agreement } \\
\text { - Require } 8 \text { hrs break between shifts } \\
\text { - No weekly limit on overtime } \\
\end{array}$ & $\begin{array}{l}\text { - Overtime Payment: time and } 1 / 4 \text { Requires } \\
\text { authorisation and mutual agreement for } 4 \\
\text { consecutive shifts } \\
\text { - Require } 12 \text { hrs break between shifts } \\
\text { - Limit on overtime: } 10 \mathrm{hrs} \text { per week }\end{array}$ \\
\hline Provisions & $\begin{array}{l}\text { - Free meals (except housekeepers) } \\
\text { - } 1 / 2 \mathrm{hr} \text { unpaid meal break } \\
\text { - } 2 \times 10 \text { min paid breaks }\end{array}$ & $\begin{array}{l}\text { - Free meals } \\
\text { - } 1 / 2 \mathrm{hr} \text { unpaid meal break } \\
\text { - } 2 \times 10 \mathrm{~min} \text { paid breaks }\end{array}$ \\
\hline $\begin{array}{l}\text { Holidays/Leave } \\
\text { Entitlements** }\end{array}$ & $\begin{array}{l}\text { - Annual Leave: } 3 \text { weeks/yr; } \\
4 \text { weeks for senior positions } \\
\text { - Statutory Holidays: } 11 \text { days/yr } \\
\text { - Special Leave: } 7 \text { days/yr after } \\
6 \text { months' employment } \\
\text { (maximum accumulation of } 20 \text { days) } \\
\text { - Parental Leave: as per legislation }\end{array}$ & $\begin{array}{l}\text { - Annual Leave: } 3 \text { weeks/yr; } \\
4 \text { weeks after } 7 \text { yrs of employment } \\
\text { - Statutory Holidays: } 11 \text { days/year } \\
\text { - Special Leave: } 5 \text { days/yr after } \\
6 \text { months' employment } \\
\text { (no maximum accumulation) } \\
\text { - Parental Leave: as per legislation }\end{array}$ \\
\hline $\begin{array}{l}\text { Union } \\
\text { Membership }\end{array}$ & $\begin{array}{l}\text { - None of the internal staff belong to a } \\
\text { union*** }\end{array}$ & $\begin{array}{l}\text { - } 65 \% \text { (100 staff). Mainly in Rooms } \\
\text { Division, Restaurant, Maintenance }\end{array}$ \\
\hline
\end{tabular}

Table 2b: Employment Conditions as of February 2004.

\begin{tabular}{|c|c|c|}
\hline & Call Centre A & Call Centre B \\
\hline Working Hours & $\begin{array}{l}\text { - Overtime Payment: normal rate } \\
\text { - Highly variable working hours }\end{array}$ & $\begin{array}{l}\text { - Overtime Payment: normal rate } \\
\text { - Limit on working hours: part-timers }-38 \\
\text { hrs p/w; casuals: } 28 \mathrm{hrs} p / \mathrm{w} \\
\text { - No set timing/number of hours } \\
\text { - Determined by roster }\end{array}$ \\
\hline Provisions & - 10 min unpaid break every $11 / 2 \mathrm{hr}$ & $\begin{array}{l}\text { - } 10 \text { min unpaid break every } 1 \frac{1}{2} \mathrm{hr} \\
\text { - One } 15 \mathrm{~min} \text { unpaid break during a shift } \\
\text { - Another } 15 \text { min unpaid break after } 8 \mathrm{hrs} \\
\text { work. }\end{array}$ \\
\hline $\begin{array}{l}\text { Holidays/Leave } \\
\text { Entitlements** }\end{array}$ & - Annual Holiday pay as per legislation & $\begin{array}{l}\text { - Sick Leave: } 5-10 \text { days/yr depending on } \\
\text { no. days worked } \mathrm{p} / \mathrm{w} \\
\text { - Statutory Holidays: } 11 \text { days/yr } \\
\text { - day in lieu for public holidays } \\
\text { - double pay for Anzac and Waitangi day } \\
\text { - Parental Leave: as per legislation } \\
\text { Bereavement Leave: } 3 \text { days/yr }\end{array}$ \\
\hline $\begin{array}{l}\text { Union } \\
\text { Membership }\end{array}$ & $\begin{array}{l}\text { - None of the internal staff belong to a } \\
\text { union. }\end{array}$ & $59 \%$ (105 staff) \\
\hline
\end{tabular}

\section{Key Findings}

Certain themes related to the research questions emerged that require further exploration - namely:

- The perceived levels of stress

- Coping mechanisms based on the individual

- Sources of stress; and

- Compliance status quo.

One of the most puzzling aspects of this study was the respondents low to moderate perceived levels of stress, with few interviewees acknowledged that they had stressrelated health problems. The Department of Labour interviewees also noted that the service sector had poorly organised job categories (Interview tape OSHI 17/09/2004) and as such involves a multitude of stress factors, for example, rude and dangerous customers and fatigue (7-day operation and shiftwork) in comparison to high-stressed jobs that are inherently stressful by their nature (e.g. air traffic, ambulance and policing).

The question is "why"? Could it be that service workers are at risk of the "boiled frog" syndrome - that is, they are unaware of the impacts of an increasingly dynamic and stressful working environment on their health and well-being? Perhaps as there is some evidence in both these studies and others that there is widespread acceptance by those in the service sector that stress is an 
integral part of the job (e.g. shiftwork, long working hours and emotional demands) or as some of the interviewees stated: "it's part of the package" and others described it as a "burn and churn" working environment (Interview tape HRI 06/11/2004). That is, service workers are expected to tolerate occupational stress and accept that their job is demanding and that they will have to work long and irregular hours.

Another possible explanation for this general tolerance of stress is that in each of the case studies, management tended towards a unitarist approach in managing employment relations. Put simply, under a unitarist style of management, dissidence is not acceptable and disagreements are the result of management's failure to communicate its goals effectively (Blyton and Turnbull, 1998). The interview data reveals that employees are not expected to challenge managerial decisions or their employer's right to manage; to do so would result in the disapproval by their managers. Nonetheless, this and other studies (for example, Kahn, and Byosiere, 1992; Cartwright et al. 1995; Houtman et al. 1998; Bohle et al. 2004; etc) indicate that even the most dedicated and compliant workers have limits and that they are prone to stress-related ill-health and social problems if they are exposed to prolonged stressful working conditions.

A second theme that emerged from the findings is that the coping mechanisms rest almost entirely on the individual and that this self-management approach was generally accepted by those interviewed from the case studies. Rather than challenging management over the decisions concerning conditions of work (see Lukes, 1993), typically individual employees adapted to stressful situations by applying a number of personal strategies that ranged from physiological techniques (deep breathing, etc.) to social support mechanisms. Such strategies are concentrated at the individual level rather than the organisational or industry levels of analysis. This suggests an abrogation of the regulatory duty of care in which the responsibility for health matters rests no longer with the employer, but with the employee.

The prevalence of a close working relationship between employers and employees in the hotel and call centre case studies suggests that social support may play a critical role in neutralising employees' experience of occupational stress. Given the all consuming aspect of hospitality and call centre work in terms of long and unsocial hours, it is not unusual for work teams to provide a "second family" for most hospitality and call centre workers. In this sense, the camaraderie in the workplace provides an essential source of motivation, belongingness and support, especially for those who are strong team players, which may in turn strengthen employees' commitment to their organisation in spite of unsatisfactory or stressful working conditions. According to Casey (1995; 2002), this "family culture" can be manipulative in nature in which employees are subconsciously drawn into the life of the organisation while subsuming their own personal lives and families. Furthermore, with unitarist style of management, there is a single source of authority (management) and each team or division was unified in a common purpose, namely the success of the team, and ultimately the organisation.

The findings also alluded to other possible coping mechanisms - namely to vacate the job or to take annual holidays, sick leave or leave without pay - once stress levels become intolerable. Most interviewees commented on the high absenteeism rate and the high staff turnover in the hotels and call centres, where it is common for employees to leave their jobs without giving notice. However, the service sector, (and in particular the call centre and hotel industries) is notorious for its high rate of casualised labour and it transient working population. Therefore, it would be a misnomer to state that the high staff turnover was entirely the result of occupational stress. Nonetheless, one of the possible outcomes of an increase in the rate of stress-related illnesses could be growing number of absentees in the future (see Cooper and Cartwright, 1994). In addition, poor employment conditions associated with this sector have been identified in a number of studies as the primary causes its high employee turnover (Wasmuth and Davis, 1983; Woods and Macaulay, 1991; 1998; Hinkin and Tracey, 2000).

A third theme was the sources of stress. Typically, employees and employers as well as stakeholders emphasised the resource constraints, such as work overload, time constraints, shortages of staffing and dealing with difficult customers, as influential factors in occupational stress. Staff shortages (either as a result of financial constraints or labour shortages) meant that sometimes workers, particularly the supervisors/junior managers, were required to work longer hours. Furthermore, most executive and line managers worked 50 hours or more per week. Comments about the general working conditions in New Zealand - that is, working longer and harder - were frequently mentioned by service workers interviewed. It is estimated that almost $22 \%$ of New Zealand workers work more than 50 or more hours per week (Messenger, 2004; Statistics New Zealand, $2004 \mathrm{c}$ ). By contrast, in most EU countries, the number of people working 50 hours or more per work remains well under 10 per cent, with figures ranging from 1.4 per cent in the Netherlands to 6.2 per cent in Greece and Ireland (Messenger, 2004). Although the link between hours worked, ill health and injuries is still debatable, there is growing evidence that working beyond 48 hours a week doubles the risk of coronary heart disease (Wedderburn, 1996; Smith, 1993; 1999; Quinlan and Bohle, 2000; Messenger, 2004; Gold, 2005). Similarly, a New Zealand study by O'Driscoll revealed that as daily working hours are increased from eight to 12 , there are detrimental effects on health and safety over time (cited Macfie, 1998). Other New Zealand studies on shift work show that people who cope better are those with well-established community and family support networks, maintained during periods outside work (Wilson, 1995; Rasmussen and Lamm, 2002).

Inter-personal relationships, particularly the tensions between subcontractors and non-subcontracted employees, were also identified as a source of stress by the employees and managers. The use of subcontractors is an extensive and increasing practice in the hospitality industry (although this common practice was not 
mentioned by the key stakeholders interviewed). There are a number of studies that shows subcontracted workers in general have higher rates of injury and illness, compared to non-subcontracted workers as they are often required to carry out the more hazardous duties that the host company does not wish to undertake (Quinlan, Mayhew and Ferris, 1997: Tucker, 2002).

A fourth theme was that there is a compliance status quo in which the management in both the hotels and call centres studies made no special provision to incorporate work-related stress as a workplace hazard into their existing OSH policies and practices. According to the managers interviewed, stress constituted a minor component of the job and as such they argued that major changes are unnecessary because they already have in place adequate health and safety systems and an "opendoor' policy. However, employees interviewed reflected a somewhat contradictory perspective of the application of these systems and in particular, the "open lines of communication". For instance, in the hotel case studies, the majority of employees interviewed (with the exception of the divisional managers who directly report to top management) indicated that it would be very unlikely that they would approach management with a complaint about their stress levels. The general belief amongst employees was that while senior management were sympathetic towards their staff, they were not proactive in remedying the stressful situations. In addition, there is a high turnover of line managers, creating constant variations in capabilities and people skills (and differing levels of support) at the supervisory level.

In short, the majority of employees did not consider their superiors suitable to alleviate the conditions causing stress. These sentiments, however, are juxtaposed with the comments made by 23 interviewees (out of 35 ) that there is intimate teamwork and interdepartmental relationship and that their working environment is very friendly. In addition, seven interviewees (out of 35) noted that most senior and line managers are supportive and approachable and that management has an open door policy. Such comments could be described as attuned with the unitarist perspective, as discussed above. Such contradictory findings are supported in the literature where a number of studies show that there is a great deal of managerial rhetoric on reducing stress levels, but with little evidence of real commitment and that employers often underplay the stress suffered by employers (Houtman et al. 1998; Lamm, 2002).

The other area in which compliance status quo was exhibited was in the lack of awareness of the recent OSH reforms, including the addition of stress and fatigue. Despite the fact that both hotel case studies have wellinformed OSH Committee meetings, the findings indicate that hospitality employees, in the main, are unaware of the legislative change and hence were unable to comment substantially about such changes. The possible reasons for this low level of awareness amongst the employees interviewed are: the general lack of worker participation and collective hargaining arrangements (in which most interviewees did not know what was meant by "collective agreement") as well as a weak trade union presence. There is overwhelming evidence that worker participation, collectivism and a strong trade union presence greatly enhances both the level of awareness of $\mathrm{OSH}$ requirements and the health and safety of employees (Weil, 1991; Walters, 1997). However, given that both hotels display a unitarist approach to employment relations (that is, trade unions are viewed as an unnecessary intrusion) and the precarious and nonstandard nature of employment in the industry, it is not surprising that these elements are largely absent.

\section{Conclusion}

This paper has attempted to expand the level of analysis by incorporating employment relations features in its investigation of the complexities of occupational stress within the case studies. As a result of applying an employment relations perspective, a number of interesting aspects have emerged. First, the employees have low to moderate perceived levels of stress and yet there is no evidence that the stress levels are declining or that their conditions and pay rates are improving to any large extent. Also, the absenteeism and staff turnover rates are high and are increasing. In short, there is no conclusive answer as to why the interviewed employees perceive their stress levels to be low to moderate. It may be important that, under the unitarist frame of reference, management has a low tolerance to any dissent employees.

Second, although there were some employer initiatives to reduce or manage workplace stress, coping with stress is still essential the domain of the individual employee. However, this focus on the individual should not preclude a wider examination of workplace stress. That is, the employment factors, such as poor working conditions, the lack of resources, etc., which contribute to stress cannot be overlooked or diminished. Third, it is advocated that it is necessary to move the traditional research of occupational stress beyond the narrow confines of a mono-disciplinary approach with a single level of analysis to a multidisciplinary approach with multiple levels of analysis that underpins the employment relations perspective. By expanding the purview of the research on occupational stress in the hospitality industry, it will hopefully shed more light on the wider factors that contribute to occupational stress in this and other related industries.

\section{Future Research}

Whether or not the commodification of "emotional" and "aesthetic" contributes to heightened level of stress amongst service workers is still unclear and further research is required in this emerging area. In addition, there is a need to undertake a more detailed analysis of the OHS conditions of workers not only in the hotel and call centre industries but also to expand the investigation to other service industries. 
Notes

1 See Brickell v Attorney-General [2000] 2 ERNZ 329

2 See Attorney-General v Gilbert [2002] 2 NZLR 342

3 See Hatton v Sutherland [2002] 2 All ER 1 (CA)

4 See Cartwright and Cooper (1997) for further details on the six environmental sources of stress.

\section{References}

Blyton, P. and Turnbull, P. (1998) The Dynamics of Employment Relations. London: MacMillan Press.

Bohle, P., and Quinlan, M. (2000). Managing Occupational Health and Safety: $A$ Multidisciplinary Approach (2nd ed.). Melbourne: MacMillan.

Bohle, P., Quinlan, M., Kennedy, D. and Williamson, A. (2004). Service or servitude? Health and safety in call centres and 5-star hotels. Proceedings of the 7th IIRA European Congress, Lisbon, Portugal, 7-11 September (CD ROM).

Caplan, R.D., Cobb, S., French, J.R.P., Harrison, R. V., and Pinneau, S.R.J. (1975). Job Demands and Worker Health. Washington DC: H.E.W. Publication.

Cartwright, S., and Cooper, C.L. (1997). Managing Workplace Stress. Thousand Oaks: Sage.

Cartwright, S., Cooper, C.L., and Murphy, L.R. (1995). Diagnosing a healthy organization: A proactive approach to stress in the workplace. In Murphy, L.R., Hurrell Jr, J.J., Sauter, S.L. and Kieta, G. (Eds.), Job Stress Interventions (pp. $217-$ 233). Washington, DC: American Psychological Association.

Casey, C. (1995). Work, Self and Society: After Industrialism. London: Routledge.

Casey, C. (2002). Critical Analysis of Organizations: Theory, Practice, Revitalization. London: Sage.

Cooper, C.L., Dewe, P.J., and O'Driscoll, M.P. (2001). Organizational Stress: A Review and Critique of Theory, Research, and Applications. Thousand Oaks: Sage.

Cox, T. (1988). Organizational health. Work and Stress, 2, 1-2.

Gold, D. (2005), Workplace Stress, Geneva: ILO.

Hart, P.M., and Cooper, C.L. (2002). Occupational stress: toward a more integrated framework. In
Anderson, N. Ones, D.S., Sinangil, H.K., and Viswesvaran, C. (Eds.), Handbook of Industrial, Work and Organizational Psychology (Vol. 2, pp. 93-113). London: Sage Publications, Inc.

Health and Safety in Employment Amendment Act, 2002.

Hinkin, T.R., and Tracey, J.B. (2000). The cost of turnover: putting a price on the learning curve. Cornell Hotel and Restaurant Administration Quarterly, 14-21.

Hochschild (1983). The Managed Heart. Berkeley: University of California Press.

Houtman, I.L.D., Goudswaard, A., Dhondt, S., van der Griten, M.P., Hildebrandt, V.H., and ver der Poel, E.G.T. (1998). Dutch monitor on stress and physical load: Risk factors, consequence and preventive action. Occupational and Environmental Medicine, 55, 73-83.

Kahn, R.L., and Byosiere, P. (1992). Stress in organizations. In Dunnette, M.D. (Ed.), Handbook of Industrial and Organizational Psychologv (pp. 571-648). Chicago: Rand McNally.

Kompier, M.A.J., Geurts, S.A.E., Grudemann, R.W.M., Vink, P., and Smulders, P.G. W. (1998). Cases in stress prevention: the success of a participative and stepwise approach. Stress Medicine, 14, 155-168.

Korczynski, M. (2002). Human Resource Management in Service Work. Hampshire: Palgrave.

Lamm, F. (2002) OHS in Small Businesses In Lloyd, M. (ed) Occupational Health and Safety in New Zealand: Contemporary Social Research. Wellington, Dunmore Press, pp93-118.

Lukes, S. (1993) Three Distinctive Views of Power Compared in Hill, M., The Policy Process, Sydney: Harvester Wheatsheaf.

Macfie, R. (1998) More Work and Less Pay, Safeguard, March-April: 18-21.

Messenger J.C. (2004) (ed.) Working Time and Workers' Preferences in Industrialized Countries: Finding the Balance (2004), International Labour Organization. London, Routledge.

Nickson and Warhurst (2004) The New Labour Aristocracy'? Aesthetic Labour in the Service Economy, Glasgow: University of Strathclyde.

Otto, R. (1985). Health damage through work stress: Is "stress management" the answer? New Doctor, 35 , 13-15.

Parkes, K. R. (1995). The effects of objective workload on cognitive performance in a field setting: a two- 
period cross-over trail. Applied Cognitive Psychologv, 9, S153-S157.

Perrewe, P.L., and Anthony, W.P. (1990). Stress in a steel pipe mill: The impact of job demands, personal control, and employee age on somatic complaints. Journal of Social Behavior and Personality, 5, 77-90.

Quinlan, M., Mayhew, C. and Ferris, R. (1997) The effects of subcontracting/outsourcing on occupational health and safety: Survey evidence from four Australian industries, Safety Science May, 25(1-3):163-78.

Rasmussen, E. and Lamm, F. (2002). Two steps forward and one step backwards: the Danish experiment with leave entitlements in the post 1993 period, AIRAANZ Conference Proceedings, Queenstown, pp403-412.

Reynolds, S., and Shapiro, D. (1991). Stress reduction in transition: conceptual problems in the design. implementation, and evaluation of worksite stress management interventions. Human Relations. 44(7), 717-733.

Sauter, S.L., Murphy, L.R., and Hurrell Jr, J.J. (1990). Prevention of work-related stress. Journal of Managerial Psychologi: 15, 227-241.

Scott-Howman, A., and Walls, C. (2003). Workplace Stress in New Zealand. Wellington: Thomson Brookers.

Semmer, N. (1997) Individual differences, work stress, and health, in Schabracq. M.J., Winnubst, J.A. and Cooper, C.L. (eds) Handhook of Work and Health Psychologi; Chichester: Wiley.

Smith, P.A. (2003) Kelnote Address: Monitoring the Impact of Shiftwork on Emplovee Well Being. XVIth International Symposium on Night and Shiftwork, Santos, Brazil, November 18-21, 2003.

Spector, P.E. (2003). Industrial and Organizational Psichologi: Research and Practice (3rd ed.). New York: Wiley.

Statistics New Zealand (2004c) Hours of work: Lahour Market Statistics www.stats.govt.nz

Tucker, D. (2002). Precarious' Non-Standard Employment - A Review of Literature. Wellington: Labour Market Policy Group, Department of Labour.

van der Hek, H and Plomp, H.N. (1997) Occupational stress management programmes: A practical overview of published effect studies, Occupational Medicine, 47(3): 133-141.

Walters, D.R. (1997). The role of regional health and safetr. representatives in agriculture: An evaluation of a trade union initiative on roving safety representatives in agriculture (No. 157/97).

Wasmuth, W.J., and Davis, S.W. (1983). Managing employee turnover. Cornell Hotel and Restaurant Administration Quarterly, 24(1), 15-22.

Warhurst, C., Nickson, D., Witz, A., and Cullen, A. (2000). Aesthetic labour in interactive service work: Some case study evidence from glasgow. The Services Industrial Journal, 20(3).

Warhburst, C., Nickson, D., Witz, A., and Cullen, A. (2000). Aesthetic labour in interactive service work: Some case study evidence from glasgow. The Services Industrial Journal, 20(3).

Warhurst, C. and Nickson, D. (2001) Looking Good and Sounding Right: Style Counselling and the Aesthetics of the New Economy, London: Industrial Society.

Watkins, J. (2003). Stress-busters. People Management. 9. $12-13$

Wedderburn, A.A.I. (1996) Compressed Working Time: Bulletin of European Studies on Time. No.10. European Foundation for the Improvement of Living and Working Conditions, Dublin.

Weil, D. (1991) Enforcing OSHA: The role of labor unions, Journal of Economy and Society, 30(1): 20-36.

Wilson, M. (1995) 'Shifting gears: The toll of shiftwork in New Zealand manufacturing' in Labour. Employment and Work in New Zealand, Proceedings for the $6^{\text {th }}$ Conference, 24-25 November, Wellington: Victoria University.

Woods, R.H., and Macaulay, J.F. (1991). Rx for turnover: Retention programs that work. Cornell Hotel and Restaurant Administration Quarterly. 30(1), 79-90.

Woods, R.H., and Macaulay, J.F. (1998). Turnover and Diversity in the Lodging Industry. East Lansing, MI: American Hotel Foundation.

\section{Authors}

Zeenobiyah Hannif

Associate Lecturer

School of Management and Marketing

University of Wollongong

NSW 2522

Australia

Zeenie(a uow.edu.au

Felicity Lamm

Senior Lecturer

Department of Management and Employment Relations

The University of Auckland

Private Bag 92019 
Auckland Mail Centre

Auckland

F.Lamm@auckland.ac.nz

Karen Lo

Masters of Commerce Student

Department of Management and Employment Relations

The University of Auckland

Private Bag 92019

Auckland Mail Centre

Silverkarenlo@yahoo.co.nz
Jeffrey Lu

Masters of Commerce Student

Department of Management and Employment Relations

The University of Auckland

Private Bag 92019

Auckland Mail Centre

Auckland

Qifeng.Lu@gmail.com 